http://spilplus.journals.ac.za/

\title{
NORMS IN BRITISH AND SOUTH AFRICAN ENGLISH
}

\author{
E. Ridge
}

1

Norms, communication and identity

In English as with all other languages, norms reflect and define common experience and are essential to efficient communication. This explains the unconscious forces which operate within society to retain language conventions. It also accounts for language prescription. A threat to norms is perceived as a threat to cultural identity.

2

Dynamic.norms: English a changing language

English has always exhibited a high degree of tolerance of deviations from norms, and a generous ability to accept variety and change. Chaucer, writing in the lith century, comments in this veln on the difference between the English of his time and earlier English.

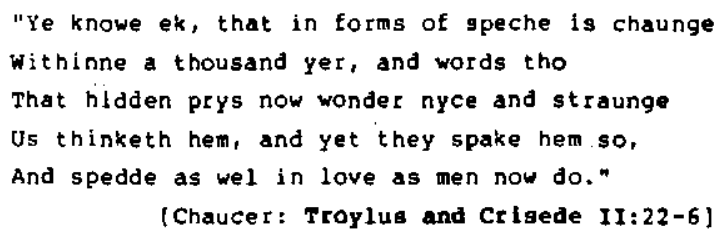


Walthan Forest -- 18 of the school children speak some language other than English in their homes (Bailey interaction may be observed in South Africa. In the face of this variety, it is remarkable that the forms of English used throughout the world are mutually intelligible.

The main differences between speech communties may be found in pronunciation. It is easy to detect the distinctive differences between the ways in which park is pronouriced in R.P. English, S.A. Extreme English, Australian English, New Zealand English and American English. However, within any one of these groups there would be differences. There is no longer the political pressure wielded by those who use "the" standard pronunciation as was the case when Received Pronunciation was accorded this status. At the $t$ ime, those in power were educated in London, Oxford or Cambridge and their political power lent authority to their particular pronuriciation.

There are sharper constraints on English that is written than on the spoken language. Written English is remarkably uniform. The norms of Standard English are maintained to a considerable extent by the great printing houses and the $t$ ir adherence to "house style" that was first introduced by Caxton. The notion of a standard English is consequentiy particularly assoclated with English in a written form.

The vocabulary of British English is generally accessible to all varieties of English as a common core. However, all national vacieties of English include some words which reflect particular or local experience. Just as Canadians have the word kuletak (a garment like an anorak), Australians have the word vorrigal (wild person or animal), South African have the words ert, lmpala and biltong.

In time, some of these words, such as SAE trek, become common property. It is regional colloguialisms which often make comprehension difficult. Australian expressions like smo o (teabreak) and cole the raw prawn would be just as alien to English speakers in Britain as the South African tackles, faggot (type of brick), cooldrink and bonsella. 
Standard English reflects the complex of linguistic and communicative norms which have been adopted over the widest area and over the widest range of usage. The ideal user of Standard English can communicate using the full range of communicative and linguistic norm conventions which are appropriate to the needs of particular situations. Oulrk (1968b:84) describes standard English as "that kind of English which draws least attention to itself". For this reason it is clearly easier to identify a standard witten Form than standard pronunciation even within Britain.

Three important developments made clear identification of norms necessary. The use of English as a literary language begun by Chaucer meant that decisions had to be taken as to which English should be considered correct.

Secondly, the Industrial Revolution marked the beginning of widespread social mobility. Rising in society meant learning the English that allowed one to "fit in" or obtain or hold down a job. Guides to normative usage have become essential for both learners and teachers. The role of governesses is also an interesting one for they had to teach their charges "correctly" and thus needed some rules that could be formulated and referred to when correcting or teaching socially accepted linguistic behaviour. Perhaps even more so as to be accepted by the class they were working for.

The third reason was the spread of English throughout the world as a second or foreign language for which there was a pressing practical need.

To some extent, then, norms must be seen as artificial. They are generally taught to prescribe what would be linguistically acceptable in a given social context. This ideal is fair enough, but it is of limited practical value. As Quirk (1968a:70) reports,

"for no period in its history has the grammar of English been described with anything approaching systematic accuracy and completeness, and writers of practical manuals in consequence have no body of full and objective data from which to draw material or on which to build a structural approach or base dependable rules...." 
Not even Quirk et al (1972) managed this when they produced their standard reference work.

There are two distinct traditions in English grammar: a prescriptive approach which finds its main authority in analogies with classical languages, and a descriptive approach which attempts to determine the normative force of particular forms within a speech community.

Prescription became popular in the eighteenth and nineteenth centuries when an urgent need was felt both for formal teaching of English and for refining and "fixing" the language. These needs fostered authoritative stances and rulings that were not valid as they reflected what certain scholars felt people should use rather than the usage that had been widely adopted by writers of standing. These scholars promulgated rules as if external pressure established good practice instead of recognizing good practice as the user's appropriately varying the forms at his disposal to fit the social context. They also Ignored English's proclivity for adopting new words and usages.

Lowth (1762:170) complained that

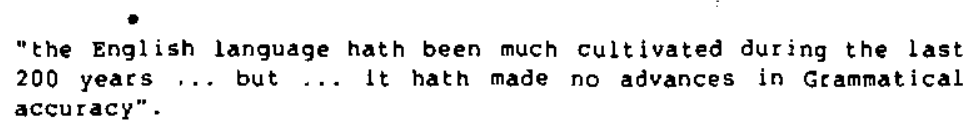

Consequently, he $(1762: i x)$ attempted to lay down rules of good usage because "our best Authors for want of rudiments of this type have sometimes fallen into mistakes, and been guilty of palpable ercor in points of Grammar". For him $(1762: x)$

"the principal design of a Grammar of any Language is to teach us to be able to judge of every phrase and form of construction. whether it be cight or not. The plain way of doing this is to lay down rules". 
http://spilplus.journals.ac.za/

Ridge 50

Bayly (1771), garris (1781) and Murcay (1795) were some of the grammarians who supported Lowth's position. Thus such proscriptions as

\footnotetext{
-..- it is wrong to end a sentence with a preposition

-.- it is wrong to split an infinitive

-- it is wrong to use me in a sentence such as It is me

were introduced and are still staples of prescriptive teaching. The decisions of these grammarians were based on the principies of logic, the rules of classical languages, etymology and aesthetics. It is interesting to note that logic was responsible for the elimination of the double nega-
} tive since two negatives make a positive.

The work of these prescriptive grammarians reflects the norms of polite letter writing in the seventeenth and eighteenth centuries and totaly ignored dramatic material or the language of proper discourse. They were concerned with the formal register. This preoccupation is still evident in modern prescriptive grammars where reference to other registers suggests deviance from the norm.

Probably examinations and schooling have been the chief means by which these prescriptions have been accepted as valid judgement, but they exist side by side. with the conventions which the gramarlans hoped to proscribe. Consequently what is tolerated and widely used in speech is considered obtrusive and objectionable in writing. Ouick (1968b:242) points out, for instance, that there are powerful conventions which forbjd the splitting of the infinitive in written language, and Fowler (1965:141) comments wittily that due to though proscribed, has literally become part of the Queen's English.

There is some evidence as far back as the eighteenth century of gramarians who identified the norms established by use. Johnson (1755), for instance, recorded middle and upper class usage. The most useful work thus far has arisen from material gathered for the Survey of Engligh Usage project iquirk 1968a). This project led, first, to The Gramar of Contemporary minlish (quirk et al 1972). A Universtty Gramar of English, based on it, records as "especially informal usage" the use of objective forms as sub- 
ject complements: e.g. "I thought it was her" louirk and Greenbaum 1972:54). As another development from this project, Leech and svartvik (1975) have produced A Comunicative Gramar of English which explores the constituent elements of both communicative and $l$ inguistic norms.

Dictionaries establish norms. Some set out to do so: others, simply by recording certain usages, give them currency.

The notion of dictionary as legislator was established in 1755 by Samuel Johnson's Dictionary of the English Language. Johnson asserted firmly

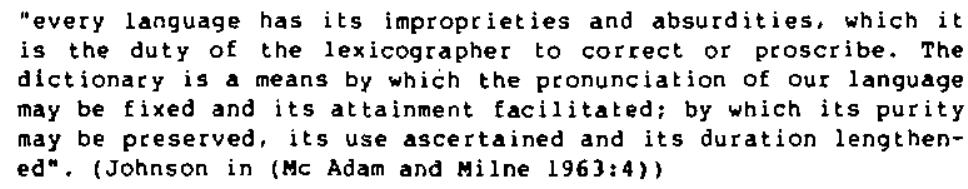

Users consideced his work, and that of succeeding lexicographers, as an authority to whlch they might have recourse on points of usage, much as the French did their academy.

The second tradition is firmly grounded in A New English Dictionary on Bistorical principle (NED), now known as The Oxford English Dictionary (OED). Here the lexicographer is affirmed as an objective recorder of actual usage. So the oxp "embraces not the standard language of literature and conversation, whether current at the moment or obșolete, or archaic, but also the main technical vocabulary and a huge measure of dialectal usage and slang". It should not be, taken as an accurate guide to current usage. As the Editors of Webster's New World Dictionary of the American language 11953:vii) point out, "a living language will not permit itself to be immutably pinned down". 
http://spilplus.journals.ac.za/

The oxford English Dictionary is nevertheless seen as the standard reference.

"All the world looks to The Oxford Dictionary as the highest authority on all aspects of our language". (Potter 1950:127)

This may bring it close to being it "a malevolent literary device for cramping the growth of a language and making it hard and inelastic" (Bierce 1971:96). But it was Johnson's dictionary that firmly established the dictionary as a conservative and standardizing agency for the spelling of English. Spelling is no longer open to much experimentation or individuality. "Cant't even spell" is often a harsh jibe at an individual's level of education. According to Baugh (1951:389), two factors make attempts at spe1ling reform founder: innate conservatism, and the etymological value of conventional orthography (the Greek ' $\mathrm{ph}$ ' for / $f /$ in. telephone and the French ' $c$ ' for $/ s /$ in cede and receive). Where attempts at reform have been succegsful, Brook (1958:103) points out that the new spelling has readily been absorbed into the language as a variant e.g. civilisation and ctoilization, connexion and connection. However, many people still passionately argue such points as the respective merits of "-ise" or "-ize" endings. The pressure to conform to a norm is felt most strongly in the area of spelling.

Branford (1978) produced a descriptive dictionary while Beeton and Dorner (1975) were more concerned to record acceptable usage. Both have had a normative effect in giving formal recognition to South African English. A journal, English Usage in Southern Africa, makes it possible Eor educated usecs to arrive at some conclusions. as to what may be seen as a valid part of South African English. 
http://spilplus.journals.ac.za/

Ridge

Bodies concerned with norms of English usage in Britain and South Africa

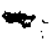

In Britain and South Africa, as is the case in virtually every country as far as a taught language is concerned, there are examining boards which are in a position to insist on the observance of language norms (particularly those which lend themselves to examination). In the past, "correct" English was requiced, but, increasingly, the ability to produce language which meets both linguistic and communicative norms will be tested.

An academy such as those in Spain. France or even South Af rica (for Afrikaans) has never been established in Britain. Baugh (1958:318f) oriefly sketches the short-lived attempt to refine and $f i x$ the language in the eighteenth century. The attitude of Englishmen in general then prevails today.

"Englishmen have always been moved by a spirit of personal liberty in the use of their language".

Or, as Johnson put it, in commenting on Swift's Proposal (1712):

"The certainty and stability which contrary to all experience he thinks attainable, he proposes to secure by instituting a academy, the decrees of which evecy man would have been willing. and many would have been proud to disobey". (Baugh 1958:325)

6.1

The English Association

The English Association is an international body first established in Britain. It has branches throughout the English speaking world, including South Africa. It takes as its aim "To promote the knowledge of English language and literature and to uphold the standards of English". It has no legislative power, and functions rather more as a group of people determined to see English Elourish and so provide occasions to fulfil their aim. Something of the limitation on their authority may be seen in Nesfield's account (1922) of the English Assocjation's being virtually ignored in the decisions relating to English made by the Joint Committee on Grammatical Terminology. 
The English Academy operates vety differently from its Afrikaans counterpart. Whilst "Die Akademie" sees its role as to give rulings, the Engligh Academy rarely does. It has inaugurated an English Language Service (Grammarphone) to offer advice to people on matters of usage. Professor $R$. sand 's comments $(1904: 146)$ highlight the difference in focus between the Academy and Die Akademie.

"Frankly. what I feared was that the Academy office would be deluged by requests from the advisers (not only members of the public) all over the country wanting all manner of rulinas which in the continual flux and expansion of a language so hospitable (or you might say, so indiscriminate of appetite) as English could prove a daunting if not impossible task."

It does enjoy some status and is consulted by official agencies. The sabs is at present investigating the extent to which uniformity may be attained in the house-style of various government organizations so proposals may be submitted to the S.A. Akademie vir Wetenskap and Kuns. When it discovered anomalies in the English writing conventions of source items and abbreviations, it looked to the Academy to appoint a working group to consider these questions and make recommendations, "bearing in mind the possibility of establishing a uniform system of abbreviations in the RSA" (Perceira $1984: 7)$.

Its attempts to influence usage have not been greatly successful. The pronunciation of kilometre provides a good example. The academy suggested ['kilau,mi:to] to the SABC on the British model but it is [ki'lomito] that has becone established in ordinary usage. Not that, the SABC has always so readily taken its advice. Attempts to persuade the broadcasting company to use broadcasters whose delivery is acceptable to the ear of English speakers (i.e. characterized by a sense of idiom, style and proper intonation) has not had concrete results (Perreira 1984:6f).

\section{The influence of the media on British and South African English}

Britain has a number of established publishing houses as well as the BBC which effectively uphold norms of usage. This is done in two ways. First. a section of the British public is nighly critical and regularly airs its 
$v$ iews in journals such as The Listener. Second, language specialists are employed to act as watchdogs.

In South Africa as has already been noted, the SABC has been strongly criticized by the Acadeny.

Speakers of English in South Africa share with the British the assumption that English has an entrenched position. Its long history has shown that it has extraordinary powers of survival. Not even years of having no status, as in Norman England, have endangered it. A vigorous Middle English emerged, although strongly influenced by French, and established itself as the language used by all people living in England. It is an international language which, as Maley (1985:32) has pointed out, has even led to the disappearance of local languages in some cases. In South Africa English has remained the official language in the independent homelands. It is clear that there is little fear that it is endangered by Afrixaans. The English speaker will never have to fight for the existence of his. language as the Afrikaans speaker had to do for his. It is obvious that there is less pressure on the English-speaking people to protect their language by means of absolute rulings.

\section{American influences on British and South African English}

As we have already noted, English has a ceceptivity to new words and usages. It has borcowed freely and zoreign words often do not reveal themselves as such. Who recognizes the French origin of uncle, aunt or cougin; the Dutch of aloof, skipper, rover or landscape; the Spanish of unbrella or Influenza? These words have moved in quite naturally to fill a semantic gap. Nor has English argued for the "true" word to be upheld against the intruder. English has a richer semantic field through being able to draw on synonyms to provide subtle shades of meaning and tone. Think, for instance, of royal, regal, kingly, imperial and majestic. A word taken from another language can be confined fairly closely to its defined meaning providing a jegree of energy and precision to its role in English.

When the central role of America in the economic sphere is considered, it is not surprising that Americanisms have taken hold in the world of business and entertainment. 
To an increasing extent advertifers use American accents or expressions as evidence of success. In South Africa we are told

Beef has it all.

--_ Aint it nice, I bought it with iy slice.

--- cleans great. New Close Op. It's got it all together.

In gritain the influence is not as obvious. Nevertheless they hear children of today play hard - and they need to eat hard, too.

8.2 Americanisms in journalism

American influence is more pervasive in newspapers and news broadcasts because it is less easy to detect. In $B r i t a i n$, the established newspapers have language editors who monitor articles to see that language policy is maintained. Nevertheless quotations from American speeches are published. svejcer (1978:i58) notes that in their use of Americanisms the news media outstrip the idiolect of the average Englishman.

South African journalism is more deeply influenced. Mr. H.F. Snifders has pointed out to me that The Argus, a conservative South African newspaper seems to have no language policy. It uses the American spelling percent but the British programmes. It also uses such Americanisms as vote-catcher, face up to, presently in the news, and top south African journalists whilst generally using English semantic norns. Hyphenation and punctuation are also inconsistent as may be seen from "... the face-the-press version of Eyeline should be a 'mikes open, notebooks open' situation". It is likely that this newspaper will beccme increasingly American as far as the business section is concerned. South African business periodicals also tend to fall back on American usage as can be seen in phcases such as macro-econowic climate, roll-back of indexation of taxes, [cssh] going into call, the stayaway has impacted significantly on business, all from Pinance Week, November B-14, 1984 . 
http://spilplus.journals.ac.za/

These examples are easy to identify but may still be regarded as part of a particular register. According to Foster (1968:19) much of American idiom has become part of the standard language and most people would not recognize Americanisms for what they are. An obvious reason is their formal and phonetic closeness to standard English. In addition, they are attractively self-explanatory: up-and-coming, foolproof, brainwashing, baby-sitter, blurb, to steamroller, to hit the headlines, holding down a job.

An ironic sidelight is that words and expressions which have long since died out or became rare in British English survive in the USA. Among them are I guess ( $c f$. Chaucer), maybe, and shoe-string.

9 Language change: constitutive rules and usage norms

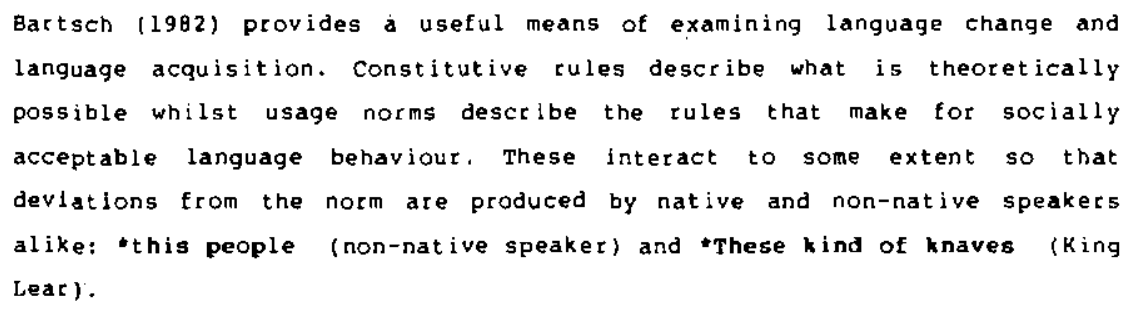


http://spilplus.journals.ac.za/

Ridge $\quad 509$ suggest that comprehensibility would be seriously affected. Other possible difficulties such as ambiguity and inaccuracy were also explored. He concludes that although a solution will not be ceadily found for it, this issue could be revealing as far as the dynamics of language and language change are concerned. Though we have seen that prescription can give rise to linguistic or communicative norms, putative sex-indefinite pronouns among them co, B, et, hesh, hir, jhe, na, person and thon have all failed (Cheshire 1985).

The clash between prescriptive and usage norms is particularly evident in the treatment of case. In contemporary English, case generally tends to be marked by position so that, the subjective case is usually found before the verb and the objective case just after the verb. Two interesting examples are the use of $I / m e$ and who/whom. Prescriptive gramars insist on the constitutively It is I (ignoring the French $C$ 'est wol and using the Latin model). Emphasis on $I$ and not we has led to hypercorrectness as in Give it to Susan and I. I told the man whow I knew would be interested, arises in a similar way. On the other hand, It is me (objective for subjective) and This is the man who I gave it to (subjective for objective) exists and 15 widely accepted.

10 Conclusion

This tentative exploration of the way norms are adopted by British and South African English has necessarily been rather selective. It does, however, indicate how a different social context (the old established language which has international currency vs. the young language spoken by a small group of people) determines the extent to which prescription and proscription are necessary. It is significant that there is not a translation equivalent in English of "notmeer" or "normering". 


\section{BIBLIOGRAPHY}

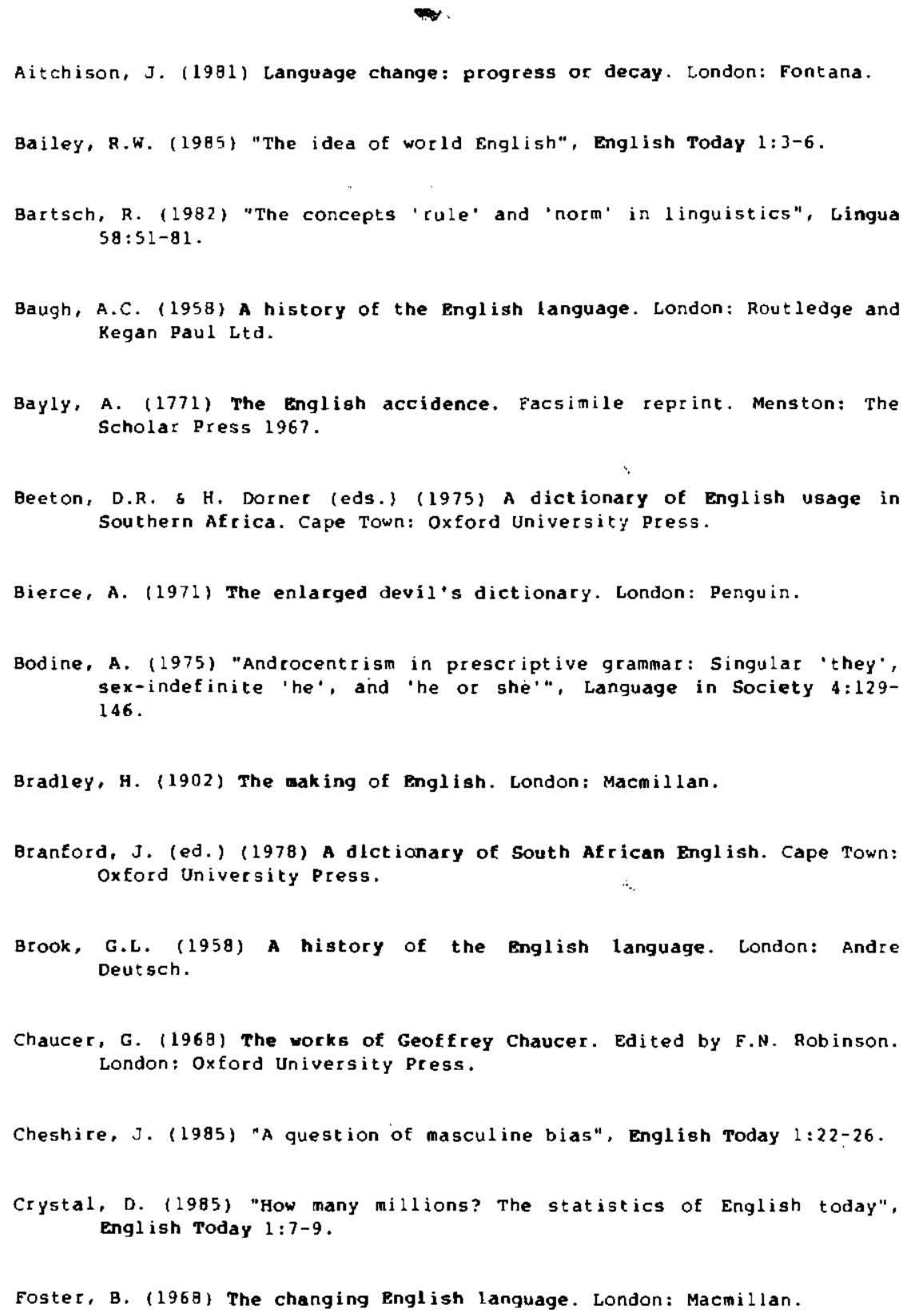

Foster, B. (1968) The changing English language. London: Macmillan. 
Fouler, H.W. (1965) A dictionary of modern English usage. Revised by $S$ ir $E$. Gowers. Oxford: Clatendon Press.

Gregory, M. \& S. Carroll (1978) Language and situation: Language varleties and their social contentp. London: Routledge and Kegan paul Ltd.

Heatherington, M.E. (1980) How language works. Cambridge, Massachusetts: Winthrop Publishers.

Jespersen, 0 . (1954) Growth and structure of the Bnglish language. Ninth edition. Oxford: Basil Blackwell.

Johnson, S. (1755) "Preface to the dictionary" in Johnson's dictionary: A modern selection. E.L. MeAdam and George Milne. London: Victor Gollancz. 1963:3-29.

Jones, D. (1967) An English pronouncing dictlonary. Thisteenth edition (rev. A.C. Gimson). London: Longman.

Lanham, L.W. K.P. Prinstoo (1978) Language and comunication studies in South Africa: Current lssues and directions in research and inquiry. Cape Town: Oxford University Press.

Leech, G.L. J, Svartvik (1975) A communicative gramar of Bnglish. London: Longman.

Lowth, R, (1762) A short introduction to Bnglish gramar. Facsimile reprint. Menston: The Scholar Press 1967.

Mackay, D.G. (1980) "On the goals, princlples and procedures for prescriptive grammar: Singular they", Language in society 9:349-367.

Maley. A. (1985) "The most chameleon of languages: Perceptions of English abroad". English Today $1: 30-33$.

Merriam-Webster, A. (1953) Webster's new world dictlonary of the Anerican language. New York: The New World Publishing Company.

Murray, J.A. (ed.) (1884-1928) The Oxford English dictlonary. Oxford: Clarendon Press.

Murray, L. (1795) English gramar. Facgimile reprint. Menston: The Scholar Press 1967. 

Nesfield, J.C. (1922) Manual of English grammar and composition. Condon:
Mactilian.

Perreira, E. (ed.) (1984) The English Academy of Southern Africa Newstetter No. $3:$ June.

Potter, S. (1950) Our language. London: Penguin.

Quirk, R. (1968a) "The survey of English Usage" in R. Quirk (ed.): Essays on the English language: Medieval and modern. London: Longman. (pp $70-87$ )

Quirk, R. (1968b) The use of English. Second edition. London: Longman.

Quirk, R. et al. (1972) A grammar of contemporary English. London: Longman.

Quirk, R. \& S. Greenbaum (1972) A university grammar of English. London: Longman.

Sands, R. (1984) "Presidential address" (1983) English Academy of Southern Af $r$ ica. The English Acadewy Review $2: 141-148$.

Svejcer. A.D. (1978) Standard English in the Onited states and England. The Hague: Mouton. 